\title{
Sistem Penilaian Pegawai Menggunakan Metode Fuzzy Multiple Attribute Decision Making (FMADM) dan Weighted Product (WP)
}

\author{
Employee Assessment System Using Fuzzy Multiple Attribute Decision Making (FMADM) and \\ Weighted Product (WP) Methods
}

\section{Ridwan Nur Septian ${ }^{1}$, Agus Sidiq Purnomo²}
${ }^{12}$ Program Studi Sistem Informasi, Fakultas Teknologi Informasi, Universitas Mercu Buana Yogyakarta, Jl. Wates Km. 10 Yogyakarta 55753, Indonesia
Email: 1ridwannyo88@gmail.com, ${ }^{2}$ sidiq@mercubuana-yogya.ac.id

\begin{abstract}
ABSTRAK
Pegawai telah mengambil peranan penting dalam proses kinerja dan kemajuan suatu instansi. Apabila pegawai tidak dapat memenuhi peraturan yang berlaku yang sesuai kriteria dan kebutuhan instansi, maka proses kinerja dalam instansi akan terhambat. Mengingat pegawai mempunyai peranan penting dalam proses kinerja dalam sebuah instansi, maka tujuan dari penelitian ini adalah menentukan penilaian terhadap pegawai, sehingga sebuah instansi dapat mempertimbangkan apakah akan menegur atau memberhentikan kerja pegawai tersebut atau tidak.

Penelitian ini menggunakan 4 kriteria sebagai parameter penilaian, agar dapat membuat keputusan yang tepat dalam penelitian ini maka digunakan metode Fuzzy Multiple Attribute Decision Making (FMADM) dan Weighted Product (WP) dengan mencari penjumlahan terbobot dari rating kinerja pada setiap alternatif pada semua atribut.

Penilaian pegawai terbaik dilakukan menggunakan empat kriteria yaitu, kehadiran, kecepatan kerja, tanggung jawab, dan kerja sama. Dan dapat di simpulkan bahwa perhitungan menghasilkan perhitungan tertinggi menggunakan sistem yaitu 0.0782 .
\end{abstract}

Kata kunci: Penilaian Pegawai, Fuzzy Multiple Attribute Decision Making (FMADM), Weighted Product (WP), Sistem Pendukung Keputusan

\begin{abstract}
Employees have taken an important role in the process of agency performance and progress. If an employee is unable to comply with applicable regulations that meet agency criteria and needs, the agency's performance process will be hampered. Given that employees have an important role in the performance process within the agency, the purpose of this study is to determine employee appraisal, so that an agency can consider whether to reprimand or terminate employee work.

This study uses four criteria as an assessment parameter, to make the right decision in this research, we use Fuzzy Multiple Attribute Decision Making (FMADM) and Weighted Product (WP) method by seeking the sum of performance rating weights on each alternative on all attributes

The best employee assessment is done with four criteria namely, attendance, speed of work, responsibility, and cooperation. And it can be concluded that calculation yield highest calculation by using system is 0,0782 .
\end{abstract}

Keywords: Employee Assessment, Fuzzy Multiple Attribute Decision Making (FMADM), Weighted Product (WP), Decision Support System 


\section{PENDAhUluan}

Ketatnya persaingan dalam dunia kerja saat ini, menuntut instansi khususnya bagi instansi pemerintahan agar pegawai dapat bekerja secara baik. Pegawai telah mengambil peranan penting dalam proses keberhasilan suatu instansi, untuk itu instansi pemerintahan harus selektif dalam memilih pegawai. Apabila pegawai tidak dapat memenuhi permintaan instansi dalam proses kinerja di dalam instansi tersebut serta pendukung operasional sesuai dengan kriteria dan kebutuhan instansi, maka dampak yang terjadi proses kinerja pegawai dalam instansi akan terhambat dan dapat menimbulkan kerugian bagi instansi pemerintahan.

Kelurahan Condong Catur adalah instansi pemerintahan, dalam rangka meningkatkan kualitas dan layanan kepada masyarakat, Kelurahan Condong Catur mengupayakan evaluasi secara terus menerus dan berkesinambungan dalam segala hal, penilaian dilakukan untuk memberikan penilaian dan menentukan manakah pegawai terbaik, karena selama ini belum ada penilaian pegawai di Kelurahan Condong Catur. Oleh karena itu dibutuhkan suatu sistem yang dapat membuat penilaian pegawai dengan mudah.

Pegawai adalah orang pribadi yang bekerja pada pemberi kerja, berdasarkan perjanjian atau kesepakatan kerja baik secara tertulis maupun tidak tertulis, untuk melaksanakan suatu pekerjaan dalam jabatan atau kegiatan tertentu dengan memperoleh imbalan yang dibayarkan berdasarkan periode tertentu, penyelesaian pekerjaan, atau ketentuan lain yang ditetapkan pemberi kerja, termasuk orang pribadi yang melakukan pekerjaan dalam jabatan negeri (Subekti, 2016).

Sistem pendukung keputusan (SPK) biasanya dibangun untuk mendukung solusi atas suatu masalah atau untuk mengevaluasi suatu peluang atau sering juga disebut sebagai aplikasi SPK. Aplikasi SPK biasanya menggunakan CBIS (Computer Based Information System) yang fleksibel, interaktif, dan dapat diadaptasi, yang dikembangkan untuk mendukung solusi atas masalah manajemen spesifik yang tidak terstruktur (Kusrini, 2007).

Dalam penelitian ini dirumuskan beberapa masalah yaitu : (1) Bagaimana merancang aplikasi Sistem Pendukung
Keputusan (SPK) untuk mempermudah penentuan penilaian pegawai terbaik? (2) Bagaimana mengimplementasikan metode Fuzzy Multiple Attribute Decision Making (FMADM) dengan Weighted Product (WP) pada sistem penentuan penilaian supplier terbaik?

Selanjutnya tujuan dari penelitian ini antara lain : (1) Merancang aplikasi Sistem Pengambilan Keputusan (SPK). (2) Dapat mengimplementasikan metode Fuzzy Multiple Attribute Decision Making (FMADM) dengan Weighted Product (WP) untuk membantu perusahaan dalam melakukan pengambilan keputusan penentuan penilaian pegawai terbaik.

Diharapkan penelitian ini dapat dimanfaatkan untuk: (1) Mampu membangun sebuah sistem dalam pengambilan keputusan penilaian pegawai terbaik. (2) Sistem pengambilan keputusan penilaian pegawai terbaik menjadi lebih cepat, tepat dan mudah. (3) Untuk mempermudah penentuan penilaian pegawai terbaik.

\section{TINJAUAN PUSTAKA}

Beberapa penelitian yang terkait antara lain seperti di Perkasa Jaya Compuretail merupakan perusahaan yang bergerak dalam bidang penjualan hardware dan perlengkapan komputer. Proses evaluasi yang terjadi sekarang umumnya adalah adanya pegawai yang langsung mendapatkan promosi untuk kenaikan jabatan yang hanya melihat pada kriteria pertama saja, tetapi pegawai tersebut belum tentu unggul pada beberapa kriteriakriteria yang lain, akan tetapi tetap mendapat promosi untuk kenaikan jabatan. Dengan adanya sistem pendukung keputusan ini, diharapkan dapat mengurangi nilai subyektif dalam pengambilan keputusan (Ananta \& Winiarti, 2013).

Perkembangan perusahaan sangat dipengaruhi oleh kinerja dari sumber daya manusia, sehingga setiap perusahaan akan berusaha mendapatkan karyawan yang berkualitas. Kendala yang biasanya dihadapi oleh perusahaan adalah sulitnya menyeleksi calon karyawan yang sesuai dengan kriteria, dikarenakan banyaknya berkas yang masuk dari para pelamar pekerjaan, sehingga dimungkinkan terjadinya pengambilan keputusan yang kurang tepat. Penerapan metode banyak digunakan untuk membantu 
menyelesaikan masalah seleksi calon karyawan salah satu metode yang diterapkan adalah Weighted Product Model. Sehingga diharapkan proses seleksi calon karyawan akan lebih tepat dan hasilnya bisa digunakan sebagai acuan dalam pengambilan keputusan secara tepat (Lestari, 2013).

Selanjutnya penelitian mengenai pemilihan laptop, hasil dari penelitian ini memberikan saran laptop sesuai dengan kebutuhan spesifikasi untuk calon pembeli dengan tingkat akurasi perhitungan 100\% berdasarkan perhitungan manual dan perhitungan pada sistem pendukung keputusan pemilihan laptop (Syafitri, et al., 2016).

Selajutnya dalam penelitian untuk penentuan supplier yang menggunakan 9 kriteria sebagai parameter penilaian, metode yang digunakan Fuzzy Multiple Attribute Decision Making (FMADM) dan Simple Additive Weighting (SAW). Berdasarkan hasil perhitungan baik metode perusahaan maupun sistem memberikan hasil yang serupa (Harjayanti \& Rozi, 2016).

Selain itu penelitian serupa yang menggunakan FMADM dan SAW juga digunakan untuk penentuan pilihan program studi yang menggunakan kriteria berdasarkan nilai akhir ujian nasional. Hasil dari penelitian ini dari penggunaan metode POLTEKES Permata Indonesia Yogyakarta maupun menggunakan sistem metode FMADM dengan SAW memiliki hasil 76,92\% yang sesuai dan 23,08\% data yang tidak sesuai dari 26 data dalam pemilihan program studi (Priatni \& Purnomo, 2017).

Fuzzy Multiple Attribute Decision Making (FMADM) adalah suatu metode yang digunakan untuk mencari alternatif optimal dari sejumlah alternatif dengan kriteria tertentu. Inti dari FMADM adalah menentukan bobot untuk setiap atribut, kemudian dilanjutkan dengan proses perangkingan yang akan menyeleksi alternatif yang sudah diberikan. Pada dasarnya, ada 3 pendekatan untuk mencari nilai bobot atribut, yaitu pendekatan subyektif, pendekatan obyektif, dan pendekatan integrasi antara subyektif dan obyektif. Masing-masing pendekatan memiliki kelebihan dan kelemahan. Pada pendekatan subyektif, nilai bobot ditentukan berdasarkan subyektifitas dari para pengambil keputusan, sehingga beberapa faktor dalam proses perangkingan alternatif bisa ditentukan secara bebas. Sedangkan pada pendekatan obyektif, nilai bobot dihitung secara matematis sehingga mengabaikan subyektifitas dari pengambil keputusan (Kusumadewi, et al., 2006).

Dalam penelitian ini menggunakan model FMADM metode WP. Langkah-langkah penyelesaianya adalah (Kusumadewi, et al., 2006):

1. Menggunakan perkalian untuk menghubungkan rating atribut.

2. Rating setiap atribut harus dipangkatkan dulu dengan bobot atribut yang bersangkutan.

3. Dilakukan perbaikan bobot $(W)$, sehingga menghasilkan bobot baru (W baru), seperti pada Persamaan 1.

$$
W_{j}=\frac{W_{j}}{\sum W_{j}}
$$

Persamaan 1

4. Mencari vektor $S$ dan dilanjut mencari vektor $V$ yang digunakan untuk perangkingan. Metode WP menggunakan perkalian untuk menghubungkan rating atribut, dimana rating setiap atribut harus dipangkatkan dulu dengan bobot atribut yang bersangkutan. Proses ini sama halnya dengan proses normalisasi. Preferensi untuk alternatif Ai diberikan seperti pada Persamaan 2.

$$
S_{i}=\prod_{j=1}^{n} X_{i j}^{w_{i j}}
$$

Persamaan 2

Dimana $\sum w j=w j$ adalah pangkat bernilai positif untuk atribut keuntungan, dan bernilai negatif untuk atribut biaya. Sedangkan preferensi relatif dari setiap alternatif, diberikan seperti pada Persamaan 3.

$$
V_{i}=\frac{\prod_{j=1}^{n} X_{i j}^{w_{i j}}}{\prod_{j=1}^{n}\left(X_{j}^{*}\right)^{w_{j}}}
$$

5. Hasil akhir perolehan dari proses perangkingan yaitu menghasilkan nilai terbesar sehingga diperoleh nilai terbesar yang dipilih sebagai altematif terbaik (Ai) sebagai solusi.

\section{METODOLOGI PENELITIAN}

Secara garis besar proses jalannya penelitian ini dibagi menjadi empat tahapan, yaitu : (1) Inteligensi, (2) Desain, (3) Pemilihan, dan (4) Implementasi dan solusi. 
Selanjutnya jalannya penelitian dapat dilihat pada Gambar 1.

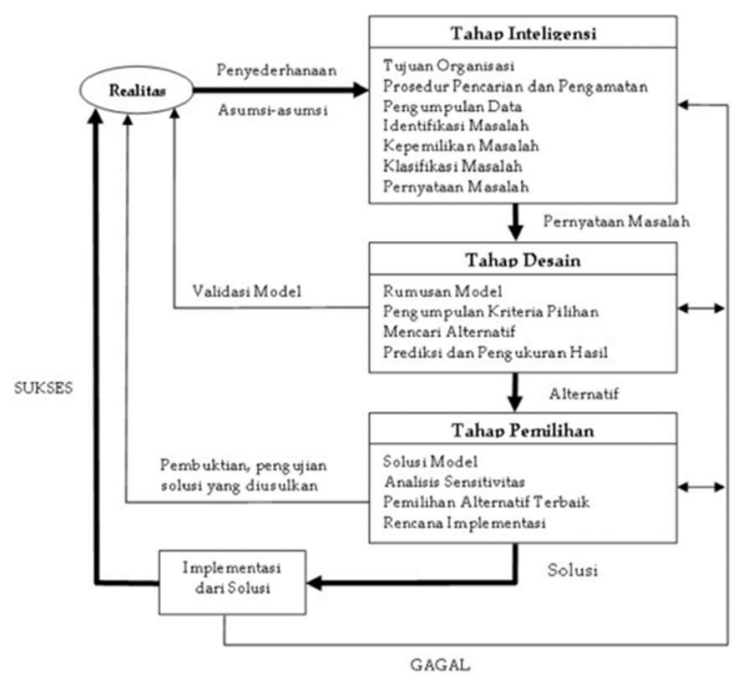

Gambar 1. Desain Sistem (Turban, et al., 2005)

\subsection{Intelegensi}

Dalam penelitian teknik pengumpulan data merupakan faktor terpenting demi keberhasilan penelitian, yaitu : (a) Wawancara, (b) Studi Kepustakaan.

\subsection{Desain}

Dalarn penyelesaian kasus tersebut berikut langkah yang harus dilakukan :

1. Menentukan Kriteria

Kriteria untuk pengambilan keputusan dapat dilihat pada Tabel 1.

\begin{tabular}{cl}
\multicolumn{2}{c}{ Tabel 1 1. Kriteria } \\
\hline Kode & Jenis Kriteria \\
\hline C1 & Kehadiran \\
C2 & Kecepatan Kerja \\
C3 & Tanggung Jawab \\
C4 & Kerja Sama \\
\hline
\end{tabular}

2. Menentukan rating kecocokan setiap alternatif pada setiap kriteria.

Rating kecocokan setiap alternatif pada setiap kriteria dinilai dengan 0 sampai 1 seperti pada Gambar 2.

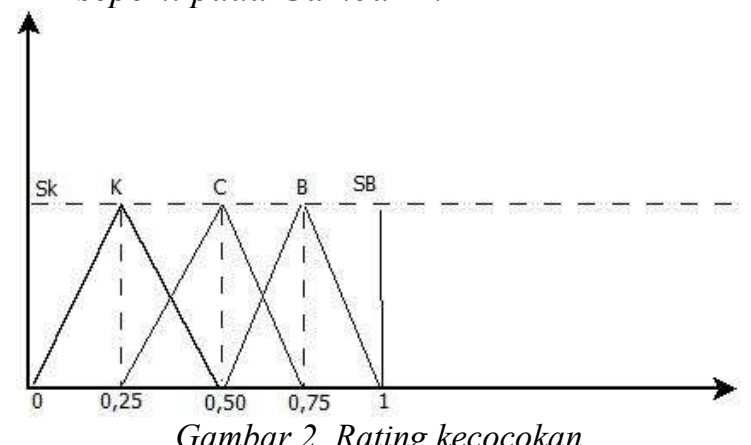

Keterangan :

- $S K=$ Sangat Kurang

- $K=$ Kurang

- $C=$ Cukup

- $B=$ Baik

- $S B=$ Sangat Baik

\subsection{Pemilihan}

Dalam tahap pemilihan ini akan dilakukan langkah dari penyelesaian dengan metode Fuzzy MADM dengan WP, yaitu membuat matriks keputusan berdasarkan kriteria, kemudian melakukan normalisasi matriks berdasarkan persamaan yang disesuaikan dengan jenis atribut sehingga diperoleh matriks ternormalisasi $R$. Rating kecocokan setiap alternatif pada kriteria diberikan seperti pada Tabel 2.

Tabel 2. Rating Kecocokan Kriteria Terhadap

$$
\text { Alternatif }
$$

\begin{tabular}{ccccc}
\hline Alternatif & $\boldsymbol{C 1}$ & $\boldsymbol{C 2}$ & $\boldsymbol{C 3}$ & $\boldsymbol{C 4}$ \\
\hline $\boldsymbol{A 1}$ & $S B$ & $B$ & $B$ & $B$ \\
$\boldsymbol{A 2}$ & $S B$ & $S B$ & $S B$ & $S B$ \\
$\boldsymbol{A 3}$ & $S B$ & $S B$ & $B$ & $B$ \\
$\boldsymbol{A 4}$ & $S B$ & $S B$ & $B$ & $B$ \\
$\boldsymbol{A 5}$ & $S B$ & $B$ & $B$ & $B$ \\
$\boldsymbol{A 6}$ & $S B$ & $S B$ & $S B$ & $S B$ \\
$\boldsymbol{A 7}$ & $S B$ & $B$ & $B$ & $B$ \\
$\boldsymbol{A 8}$ & $S B$ & $B$ & $B$ & $B$ \\
$\boldsymbol{A 9}$ & $S B$ & $B$ & $B$ & $B$ \\
$\boldsymbol{A 1 0}$ & $S B$ & $B$ & $B$ & $B$ \\
$\boldsymbol{A 1 1}$ & $S B$ & $B$ & $B$ & $B$ \\
$\boldsymbol{A 1 2}$ & $S B$ & $S B$ & $B$ & $B$ \\
$\boldsymbol{A 1 3}$ & $S B$ & $S B$ & $B$ & $B$ \\
$\boldsymbol{A 1 4}$ & $B$ & $S B$ & $B$ & $B$ \\
$\boldsymbol{A 1 5}$ & $S B$ & $S B$ & $B$ & $B$ \\
$\boldsymbol{A 1 6}$ & $S B$ & $S B$ & $B$ & $B$ \\
$\boldsymbol{A 1 7}$ & $S B$ & $S B$ & $B$ & $B$ \\
$\boldsymbol{A 1 8}$ & $S B$ & $S B$ & $S B$ & $S B$ \\
$\boldsymbol{A 1 9}$ & $B$ & $S B$ & $S B$ & $B$ \\
$\boldsymbol{A 2 0}$ & $S B$ & $S B$ & $S B$ & $B$ \\
$\boldsymbol{A 2 1}$ & $S B$ & $S B$ & $B$ & $B$ \\
$\boldsymbol{A 2 2}$ & $S B$ & $B$ & $B$ & $B$ \\
\hline
\end{tabular}

\subsection{Implementasi dan Solusi}

\subsubsection{Perancangan Data Flow Diagram} Gambar 3.
DFD level 0 dapat dilihat seperti pada 


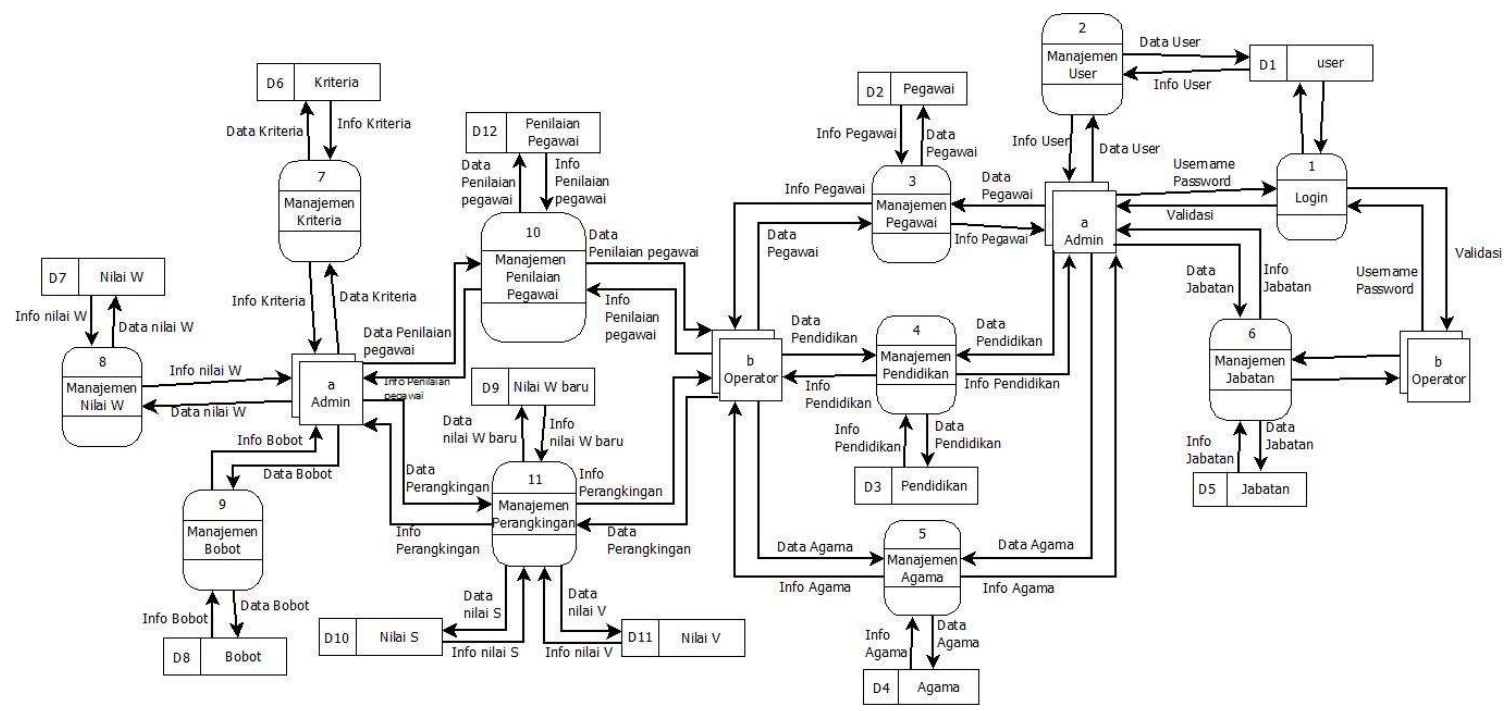

Gambar 3. DFD Level 0

\subsubsection{Flowchart Sistem} Gambar 4

Flowchart sistem dapat dilihat pada

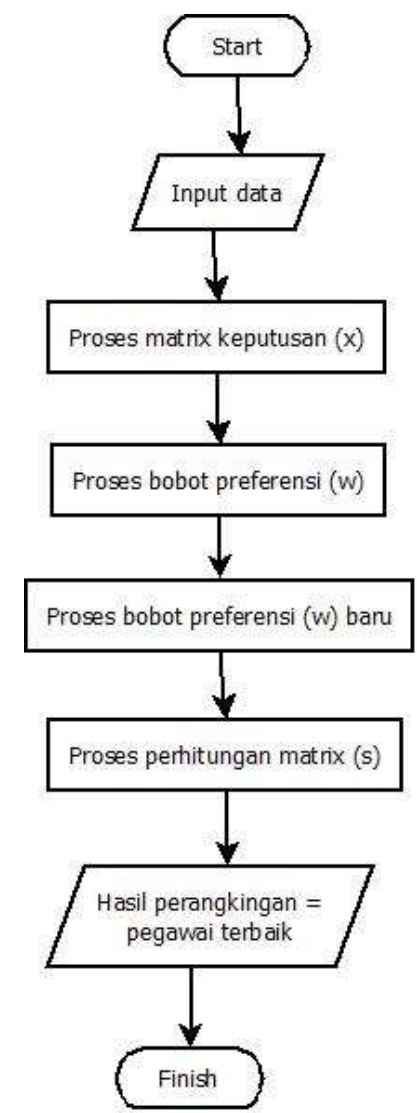

Gambar 4. Flowchart Sistem

\subsubsection{Perancangan Database}

Relasi tabel dalam penelitian ini, dapat dilihat pada Gambar 5.

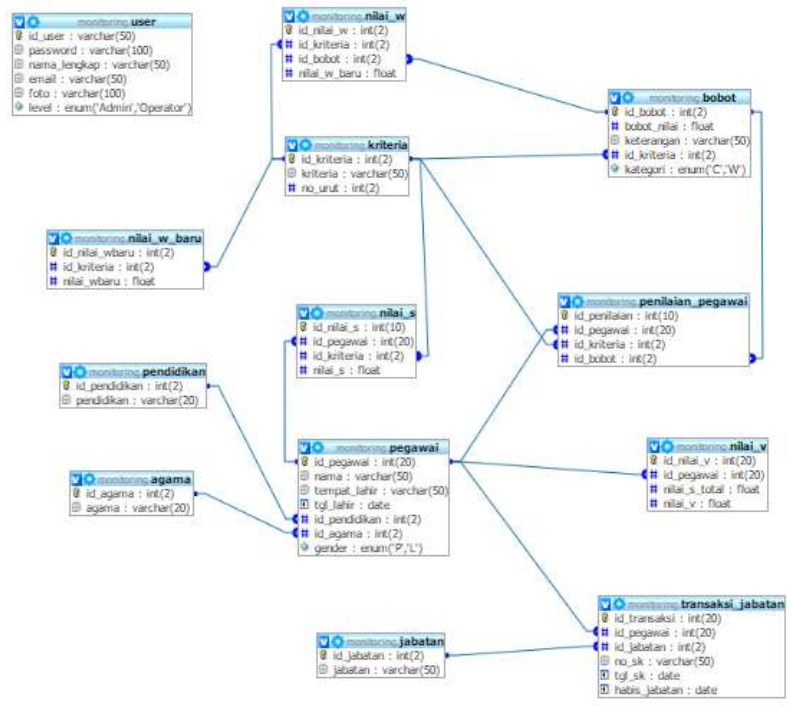

Gambar 5. Relasi Tabel

\section{PEMBAHASAN}

Matriks keputusan $X$ yang telah di konversikan dengan bilangan fuzzy berdasarkan Tabel 2, dapat dilihat pada Tabel 3.

Tabel 3. Matriks $X$

\begin{tabular}{|ccccc|}
\hline Alternatif & $\boldsymbol{C 1}$ & $\boldsymbol{C 2}$ & $\boldsymbol{C 3}$ & $\boldsymbol{C 4}$ \\
\hline $\boldsymbol{A 1}$ & 1 & 0.75 & 0.75 & 0.75 \\
$\boldsymbol{A 2}$ & 0 & 1 & 1 & 1 \\
$\boldsymbol{A 3}$ & 0 & 0.5 & 0.75 & 0.75 \\
$\boldsymbol{A 4}$ & 0 & 0.5 & 0.75 & 0.75 \\
$\boldsymbol{A 5}$ & 0 & 0.75 & 0.75 & 0.75 \\
$\boldsymbol{A 6}$ & 0 & 0.5 & 0.5 & 0.5 \\
$\boldsymbol{A 7}$ & 1 & 0.75 & 0.75 & 0.75 \\
$\boldsymbol{A 8}$ & 1 & 0.75 & 0.75 & 0.75 \\
$\boldsymbol{A 9}$ & 1 & 0.75 & 0.75 & 0.75 \\
$\boldsymbol{A 1 0}$ & 0 & 0.75 & 0.75 & 0.75 \\
$\boldsymbol{A 1 1}$ & 1 & 0.75 & 0.75 & 0.75 \\
\hline
\end{tabular}




\begin{tabular}{|ccccc|}
\hline Alternatif & $\boldsymbol{C 1}$ & $\boldsymbol{C 2}$ & $\boldsymbol{C 3}$ & $\boldsymbol{C 4}$ \\
\hline $\boldsymbol{A 1 2}$ & 1 & 0.5 & 0.75 & 0.75 \\
$\boldsymbol{A 1 3}$ & 1 & 0.5 & 0.75 & 0.75 \\
$\boldsymbol{A 1 4}$ & 0.75 & 0.5 & 0.75 & 0.75 \\
$\boldsymbol{A 1 5}$ & 1 & 0.5 & 0.75 & 0.75 \\
$\boldsymbol{A 1 6}$ & 1 & 0.5 & 0.75 & 0.75 \\
$\boldsymbol{A 1 7}$ & 1 & 0.5 & 0.75 & 0.75 \\
$\boldsymbol{A 1 8}$ & 0 & 0.5 & 0.5 & 0.5 \\
$\boldsymbol{A 1 9}$ & 0.75 & 0.5 & 0.5 & 0.75 \\
$\boldsymbol{A 2 0}$ & 1 & 0.5 & 0.5 & 0.75 \\
$\boldsymbol{A 2 1}$ & 0.5 & 0.5 & 0.75 & 0.75 \\
$\boldsymbol{A 2 2}$ & 0 & 0.75 & 0.75 & 0.75 \\
\hline
\end{tabular}

Pengambil keputusan memberikan bobot, berdasarkan tingkat kepentingan masing-masing kriteria yang dibutuhkan sebagai berikut :

Vektor bobot : $W=[0,0.25,0.5,0.75,1]$

Membuat matriks keputusan $X$ berdasarkan tabel kecocokan sebagai berikut :

$X$

$=\left[\begin{array}{ccccccccc}0.50 & 1 & 0.75 & 1 & 1 & 0.50 & 1 & 0.50 & 1 \\ 1 & 0.75 & 1 & 1 & 1 & 1 & 1 & 0.50 & 1 \\ 0.75 & 1 & 0.75 & 1 & 0.75 & 1 & 1 & 0.75 & 1\end{array}\right]$

Untuk mencari $W$ baru menggunakan
$W=[1,0.5,0.75,0.5]$

Berikut perhitungan dari pencarian $W$ baru seperti pada Tabel 4.

\section{Tabel 4. Nilai W Baru}

\begin{tabular}{ccc}
\hline $\boldsymbol{W}$ & Perhitungan W baru & Hasil \\
\hline W1 & $\frac{1}{1+0.5+0.75+0.5}$ & 0.3636 \\
W2 & $\frac{0.5}{1+0.5+0.75+0.5}$ & 0.1818 \\
W3 & $\frac{0.75}{1+0.5+0.75+0.5}$ & 0.2727 \\
W4 & $\frac{0.5}{1+0.5+0.75+0.5}$ & 0.1818 \\
\hline
\end{tabular}

Kemudian vektor $S$ dihitung berdasarkan Persamaan 2.

$$
\begin{gathered}
S_{1} \\
=\left(1^{0.3636}\right)\left(0.75^{0.1818}\right)\left(0.75^{0.2727}\right)\left(0.75^{0.1818}\right) \\
=0.0782 \\
\quad \text { Selanjutnya dihitung vektor } V \text { dihitung }
\end{gathered}
$$
berdasarkan Persamaan 3.

$$
V=0.0782
$$

\begin{tabular}{|c|c|c|c|}
\hline \multicolumn{4}{|c|}{ Kesimpulan Hasii Perangkingan Metode WP } \\
\hline No. & Kode Pegawai & Nama Pegawai & Nilai Akhir (V) \\
\hline 1 & 1 & Sugiyanto, S.Pd. & 0.0782 \\
\hline 2 & 9 & Surono & 0.0782 \\
\hline 3 & 8 & Y.Sudarno & 0.0782 \\
\hline 4 & 7 & Retnaningsih & 0.0782 \\
\hline 5 & 11 & Hery Supriyono & 0.0782 \\
\hline 6 & 13 & Murniati & 0.0727 \\
\hline 7 & 15 & Fernandya Riski H.ST & 0.0727 \\
\hline 8 & 16 & Sudarna, BA. & 0.0727 \\
\hline 9 & 17 & Marsana & 0.0727 \\
\hline 10 & 12 & Handarbe Wahyu MS. & 0.0727 \\
\hline 11 & 14 & Sunarti & 0.0654 \\
\hline 12 & 20 & Tri Sugiyatno & 0.0651 \\
\hline 13 & 19 & Wasiati & 0.0586 \\
\hline 14 & 21 & Nurul Eni K,SE & 0.0565 \\
\hline 15 & 10 & H.A. Trisusetyanto.SIP & 0.0000 \\
\hline
\end{tabular}

Kesimpulan Hasil Perangkingan, bisa dilihat pada Gambar 6.

Persamaan 1.

Gambar 6. Hasil Perangkingan

\section{KESIMPULAN}

Berdasarkan hasil penelitian maka dapat disimpulkan :

1. Penilaian pegawai terbaik dilakukan menggunakan empat kriteria yaitu, kehadiran, kecepatan kerja, tanggung jawab, dan kerja sama.
2. Hasil perhitungan tertinggi menggunakan sistem yaitu 0.0782 .

3. Sistem yang telah dirancang dengan mengimplementasikan metode Fuzzy Multiple Attribute Decision Making (FMADM) dengan Weighted Product (WP) dapat digunakan untuk membantu pegawai 
dalam melakukan pengambilan keputusan penilaian pegawai terbaik.

Saran pengembangan yang dapat dilakukan pada sistem ini untuk masa depan adalah:

1. Pengembangan fitur laporan untuk menyimpan hasil perangkingan pegawai, sehingga dapat disimpan menjadi arsip yang berguna untuk evaluasi penilaian pegawai kepada kelurahan.

2. Sebagai bahan pengembangan untuk penelitian selanjutnya yang berkaitan mengenai penilaian pegawai terbaik.

\section{DAFTAR PUSTAKA}

Ananta, P. W. \& Winiarti, S., 2013. Sistem Pendukung Keputusan Dalam Penilaian Kinerja Pegawai Untuk Kenaikan Jabatan Pegawai Menggunakan Metode Gap Kompetensi (Studi Kasus Perusahaan Perkasa Jaya Compuretail). Jurnal Sarjana Teknik Informatika, Volume Vol. 1, No. 2, e-ISSN: 23385197, pp. 574-583.

Harjayanti, J. \& Rozi, A. F., 2016. Sistem Informasi Penilaian Supplier Komputer Menggunakan Metode Fuzzy Multiple Attribute Decision Making Dengan Simple Additive Weighting. Informatics Journal, Volume Vol. 1, No. 3, ISSN : 2503 - 250X, pp. 88-95.

Kusrini, 2007. Konsep dan Aplikasi Sistem Pendukung Keputusan. Yogyakarta: Andi.

Kusumadewi, S., Hartati, S., Harjoko, A. \& Wardoyo, R., 2006. Fuzzy Multi-
Atribute Decision Making (Fuzzy $M A D M)$. Yogyakarta: Graha Ilmu.

Lestari, S., 2013. Penerapan Metode Weighted Product Model Untuk Seleksi Calon Karyawan. Sistem Informasi, Volume Vol. 5, No. 1, ISSN Print : 2085-1588, ISSN Online : 2355-4614, pp. 540-545.

Priatni, C. N. \& Purnomo, A. S., 2017. Sistem Untuk Menentukan Pilihan Pada Program Studi Menggunakan Fuzzy Multiple Attribute Decision Making (FMADM) Dengan Simple Additive Weighting (SAW) (Studi Kasus: POLTEKES Permata Indonesia Yogyakarta). Informatics Journal, Volume Vol. 2, No. 1, ISSN : : 2503 250X, pp. 54-63.

Subekti, W., 2016. Wibowo Pajak. [Online] Available at: http://www.wibowopajak.com/2012/02/ pengertian-pegawai.html [Diakses 17 July 2017].

Syafitri, N. A., S. \& Dewi, A. P., 2016. Penerapan Metode Weighted Product Dalam Sistem Pendukung Keputusan Pemilihan Laptop Berbaasis Web. SemanTIK, Volume Vol.2, No.1, ISSN : 2502-8928, pp. 169-176.

Turban, E., Aronson, J. E. \& Liang, T. P., 2005. Decision Support Systems and Intelligent Sistems (Sistem Pendukung Keputusan dan Sistem Cerdas). Yogyakarta: Andi. 